\title{
Squamous cell skin cancer in the North-west of England, 1967-69, and its relation to occupation
}

\author{
C. J. WHITAKER, W. R. LEE, AND J. E. DOWNES \\ From the Department of Occupational Health, University of Manchester, Stopford Building, Oxford Road, \\ Manchester M13 9PT
}

\begin{abstract}
During the three years 1967-69, 781 cases of squamous cell carcinoma of the skin were reported to the Manchester Regional Cancer Registry. The proportions of males to females were significantly different $(\mathrm{P}<0.001)$ among the skin cancer sites. The age-specific incidence rates were significantly different $(\mathrm{P}<0.001)$ between the sexes for the five-year age groups of 55 years and above. Full occupational histories were obtained on $598(77 \%)$ patients; a further $148(19 \%)$ patients gave one main occupation only, while the remaining $35(4 \%)$ patients were untraced. The numbers of patients observed in broad occupational groups (occupational orders) were compared with the numbers expected using the 1931 and 1951 censuses. For all skin cancer sites combined the occupations of farming and textiles were found to have highly significant excesses of $150 \%$ and $135 \%$ respectively for males. The corresponding excesses for females were $30 \%$ for textile workers and varied from $1140 \%$ to $590 \%$ for farmers, but only for the farmers were the excesses highly significant. For males the occupation of metal worker also showed excesses of $38 \%$ and $23 \%$ which were of borderline significance. The association between occupation and individual skin cancer sites was then considered. For males there were excesses in the arm for the occupational orders of chemical workers, paper/printing workers and fishermen, and in the ears for builders, but these excesses were of borderline significance. There was a significant difference $(\mathrm{P}<0.05)$ in the proportion of male patients with atopic skin conditions in each cancer site. However, this was not found for the female patients. For both male and female patients no significant associations were found between the skin site and either eye colour, residence in the tropics or smoking habit.
\end{abstract}

A review of scrotal cancer in Scotland in 1967 (Lloyd Davies, 1970) showed that, of the 18 confirmed cases from the Hospital Inpatient Index, only 12 were probably of occupational origin. A morbidity study by Lee et al. (1972) found that, of 89 cases of scrotal cancer, 84 were probably of occupational origin. The occupations at risk have been shown to be textile workers, in particular mule spinners, and metal workers, in particular automatic lathe operators. Occupations possibly at risk are road workers, dye workers, chain makers and 'Stanford jointers' (Henry, 1946; Cruickshank and Squire, 1950; Spink et al., 1964; Lee et al., 1972). Because scrotal cancer may be regarded as one specific site of skin cancer the questions arise,

Received for publication 27 February 1978

Accepted for publication 28 June 1978 to what extent skin cancer of other sites may be regarded as occupational, and which are the occupations at risk.

A morbidity study in Sweden found that occupational exposure to sunshine (outdoor work) was associated with skin cancer of the hand and arm (Wahlberg and Johansson, 1977). Emmett (1975) has stated that tar, pitch, shale and mineral oils are associated with skin cancer. A mortality survey of skin cancer in England and Wales by Atkin et al. (1949) found that agricultural workers were at greatest risk and professional classes at least risk, with miners having a similar risk to that of the general population. However, as death from skin cancer is unusual (Emmett, 1975) and data from death certificates may not be accurate (Alderson, 1976), a morbidity study should give more reliable information as to what occupations are at risk. 


\section{Method}

Particulars were obtained from the Manchester Regional Cancer Registry of all patients notified as having squamous cell carcinoma of the skin during the period 1 January 1967 to 31 December 1969. The family practitioners of the patients identified were asked about the advisability of approaching either the patient, if still surviving, or a relative. The patient or relative was then interviewed by J.E.D. using a questionnaire which sought information concerning the patient's sex, age, cancer site, race, eye colour, medical history (including atopic skin conditions), residential history, smoking history and occupational history.

An occupation might appear frequently, either because it occurs commonly in the region or because of a causal relationship between the occupational environment and the disease. To try to distinguish these, we have compared the distribution of reported occupations with the distribution of occupations recorded in the 1931 and 1951 censuses which cover the period when the majority of the patients in this study were at work (General Register Office, $1934 \mathrm{~b}, 1956 \mathrm{~b})$. We have used data for the Northwest region from the 1931 census report and for the Northern region No. 4 from the 1951 census report. These regions include the Manchester Regional Hospital Board (RHB) Area in which the subjects in the study lived at the time of notification of their skin cancer. The patients' occupations in the years 1931 and 1951 were grouped into the occupational orders used in those censuses (General Register Office, 1934a, 1956a). The 1931 census is not tabulated by age. This creates a problem because the differences between those observed in the occupational orders in our patients and those expected from the census material may be due in part to the differences in age distribution of the two populations.
Table 1 The distribution of patients by site of cancer and sex. The figures in parentheses show the number of patients with cancer of the fingers, hand and wrist

\begin{tabular}{lccc}
\hline Site & Males & Females & Total \\
\hline Lips & 18 & 3 & 21 \\
Eyelids & 10 & 12 & 22 \\
Ears & 137 & 25 & 162 \\
Face & 84 & 97 & 181 \\
Scalp and Neck & 20 & 23 & 43 \\
Scrotum & 35 & - & 35 \\
Trunk & 13 & 39 & 52 \\
Arm (fingers, hand and wrist) & $125(105)$ & $33(20)$ & 158 \\
Leg & 27 & 80 & 107 \\
Total & 469 & 312 & 781 \\
\hline
\end{tabular}

$x^{2}=166.8 ; \mathrm{df}=7 ; \mathrm{P}<0.001$

\section{Results}

There were 781 patients registered with skin cancer during the three-year period. Leck (1972, personal communication) estimated that $87 \%$ of all skin cancer cases seen during this period by hospitals in the region are registered at the Regional Cancer Registry. The Eighth Revision of the International Classification of Diseases (World Health Organization, 1967) was used to classify the skin cancers into different sites. The distribution of patients by site and sex is shown in Table 1. The proportions of males and females in each site are significantly different $\left(\chi^{2}=166 \cdot 8\right.$; df $=7 ; \mathrm{P}<0.001$ ).

Table 2 shows the age-specific incidence rates by sex, the age having been calculated in the year of registration for each patient. The incidence rates were calculated using the population figures of the Manchester RHB Area given in the Registrar General's Statistical Review of England and Wales for the years 1967, 1968 and 1969 (General Register Office, $1968,1970,1971)$. Using the binomial test of two proportions there is a significant difference

Table 2 Numbers of cases of skin cancer and incidence rates for five-year age groups by sex

\begin{tabular}{|c|c|c|c|c|c|c|}
\hline \multirow[t]{2}{*}{ Age group } & \multicolumn{2}{|l|}{ Males } & \multicolumn{2}{|l|}{ Females } & \multirow{2}{*}{$\begin{array}{l}\text { Standard normal } \\
\text { deviate } Z\end{array}$} & \multirow[t]{2}{*}{ Significance } \\
\hline & Number & $\begin{array}{l}\text { Incidence rate } \\
\text { (per million) }\end{array}$ & Number & $\begin{array}{l}\text { Incidence rate } \\
\text { (per million) }\end{array}$ & & \\
\hline $\begin{array}{l}15-19 \\
20-24 \\
25-29 \\
30-34 \\
35-39 \\
40-44 \\
45-49 \\
50-54 \\
55-59 \\
60-64 \\
65-69 \\
70-74 \\
75+\end{array}$ & $\begin{array}{r}0 \\
0 \\
0 \\
0 \\
2 \\
8 \\
16 \\
23 \\
54 \\
83 \\
87 \\
60 \\
136\end{array}$ & $\begin{array}{l}\text { 二 } \\
\text { 二 } \\
- \\
4.9 \\
18 \cdot 5 \\
34.9 \\
56.9 \\
126 \cdot 1 \\
218 \cdot 7 \\
304 \cdot 0 \\
329 \cdot 9 \\
726.1\end{array}$ & $\begin{array}{r}1 \\
1 \\
0 \\
0 \\
2 \\
7 \\
11 \\
15 \\
22 \\
24 \\
40 \\
49 \\
140\end{array}$ & $\begin{array}{l}2 \cdot 1 \\
2 \cdot 1 \\
- \\
- \\
5 \cdot 1 \\
16 \cdot 4 \\
23 \cdot 5 \\
34 \cdot 2 \\
46 \cdot 3 \\
53 \cdot 0 \\
101 \cdot 1 \\
155 \cdot 1 \\
336.2\end{array}$ & $\begin{array}{l}-1.01 \\
-1.00 \\
= \\
=0.03 \\
0.23 \\
1.02 \\
1.55 \\
4.12 \\
6.64 \\
6.06 \\
4.00 \\
6.56\end{array}$ & $\begin{array}{l}\text { NS } \\
\text { NS } \\
-\bar{y} \\
\text { NS } \\
\text { NS } \\
\text { NS } \\
\text { NS } \\
\text { P }<0.001 \\
P<0.001 \\
P<0.001 \\
P<0.001 \\
P<0.001\end{array}$ \\
\hline $15+$ & 469 & 94.9 & 312 & 56.4 & $7 \cdot 21$ & $P<0.001$ \\
\hline
\end{tabular}


Table 3(a) The occupational orders with an excess of observed over expected numbers of workers for the census years 1931 and 1951 for males. (All sites)

\begin{tabular}{|c|c|c|c|c|c|c|c|c|}
\hline \multirow{2}{*}{\multicolumn{2}{|c|}{ Occupation }} & \multirow{3}{*}{$\begin{array}{l}\text { Observed } \\
\text { no. }\end{array}$} & \multirow{3}{*}{$\begin{array}{l}\text { Observed } \\
\text { Expected }\end{array}$} & \multirow{3}{*}{$\begin{array}{l}\text { Significance } \\
\text { level* }\end{array}$} & \multicolumn{2}{|l|}{1951} & \multirow{3}{*}{$\begin{array}{l}\text { Observed } \\
\text { no. }\end{array}$} & \multirow{3}{*}{$\begin{array}{l}\text { Observedl } \\
\text { Expected }\end{array}$} \\
\hline & & & & & \multicolumn{2}{|c|}{ Occupation } & & \\
\hline $\begin{array}{l}\text { Order } \\
\text { no. }\end{array}$ & Brief description & & & & $\begin{array}{l}\text { Order } \\
\text { no. }\end{array}$ & Brief description & & \\
\hline \multirow[t]{3}{*}{$\begin{array}{r}12 \\
2\end{array}$} & $\begin{array}{l}\text { Textile workers } \\
\text { Farmers }\end{array}$ & $\begin{array}{l}77 \\
43\end{array}$ & $\begin{array}{l}2 \cdot 34 \\
2 \cdot 51\end{array}$ & $<0.001$ & $\begin{array}{r}7 \\
2 \\
27\end{array}$ & $\begin{array}{l}\text { Textile workers } \\
\text { Farmers } \\
\text { Other/undefined workers }\end{array}$ & $\begin{array}{l}43 \\
34 \\
11\end{array}$ & $\begin{array}{l}2 \cdot 38 \\
2 \cdot 43 \\
3 \cdot 21\end{array}$ \\
\hline & & & & $<0.01$ & & & & \\
\hline & Metal workers & 63 & $1 \cdot 38$ & $<0.05$ & & & & \\
\hline 14 & $\begin{array}{l}\text { Food, drink and tobacco } \\
\text { workers }\end{array}$ & 9 & $1 \cdot 78$ & $<0.1$ & 6 & Metal workers & 87 & $1 \cdot 23$ \\
\hline 18 & Builders & 26 & $1 \cdot 38$ & & 3 & Miners & 16 & 1.60 \\
\hline 1 & Fishermen & 2 & $3 \cdot 40$ & $<0 \cdot 2$ & & & & \\
\hline 21 & $\begin{array}{l}\text { Workers in mixed/ } \\
\text { undefined materials }\end{array}$ & 3 & 1.65 & $<0.3$ & 5 & Chemical workers & 8 & $1 \cdot 49$ \\
\hline 9 & Electrical workers & 9 & 1.43 & & & & & \\
\hline 6 & Chemical workers & 3 & $1 \cdot 59$ & & & & & \\
\hline 24 & $\begin{array}{l}\text { Public administration } \\
\text { and defence }\end{array}$ & 5 & $1 \cdot 30$ & $<0.5$ & $\begin{array}{l}1 \\
4\end{array}$ & $\begin{array}{l}\text { Fishermen } \\
\text { Non-metalliferous product }\end{array}$ & $\begin{array}{l}1 \\
3\end{array}$ & $\begin{array}{l}2 \cdot 51 \\
1 \cdot 32\end{array}$ \\
\hline $\begin{array}{l}17 \\
16\end{array}$ & Printers & 5 & $1 \cdot 14$ & & & workers & & \\
\hline 16 & Paper workers & 2 & $1 \cdot 30$ & & $\begin{array}{r}25 \\
8\end{array}$ & $\begin{array}{l}\text { Stationary engine drivers } \\
\text { Leather workers }\end{array}$ & $\begin{array}{r}10 \\
4\end{array}$ & $\begin{array}{l}1 \cdot 30 \\
1 \cdot 18\end{array}$ \\
\hline 5 & $\begin{array}{l}\text { Brick, pottery and glass } \\
\text { workers }\end{array}$ & 2 & $1 \cdot 12$ & $<0.7$ & 14 & Builders & 26 & $1 \cdot 13$ \\
\hline \multirow[t]{2}{*}{30} & Stationary engine drivers & 7 & $1 \cdot 24$ & & & & & \\
\hline & & & & $<0.9$ & & & & \\
\hline 25 & Professional & 10 & 1.00 & $>0.9$ & $\begin{array}{l}24 \\
22 \\
17\end{array}$ & $\begin{array}{l}\text { Warehouse workers } \\
\text { Personal service } \\
\text { Transport, communication }\end{array}$ & $\begin{array}{l}13 \\
13 \\
48\end{array}$ & $\begin{array}{l}1.03 \\
1.03 \\
1.00\end{array}$ \\
\hline
\end{tabular}

*The occupational orders for both years are arranged in decreasing level of significance, in this Table and in Tables $3 \mathrm{~b}, 4$ and 5 .

Table 3(b) The occupational orders with an excess of observed over expected numbers of workers for the census years 1931 and 1951 for females. (All sites)

\begin{tabular}{|c|c|c|c|c|c|c|c|c|}
\hline \multirow{2}{*}{\multicolumn{2}{|c|}{$\frac{1931}{\text { Occupation }}$}} & \multirow{3}{*}{$\begin{array}{l}\text { Observed } \\
\text { no. }\end{array}$} & \multirow{3}{*}{$\begin{array}{l}\text { Observed] } \\
\text { Expected }\end{array}$} & \multirow{3}{*}{$\begin{array}{l}\text { Significance } \\
\text { level }\end{array}$} & \multicolumn{2}{|l|}{1951} & \multirow{3}{*}{$\begin{array}{l}\text { Observed } \\
\text { no. }\end{array}$} & \multirow{3}{*}{$\begin{array}{l}\text { Observed/ } \\
\text { Expected }\end{array}$} \\
\hline & & & & & \multicolumn{2}{|c|}{ Occupation } & & \\
\hline $\begin{array}{l}\text { Order } \\
\text { no. }\end{array}$ & Brief description & & & & $\begin{array}{l}\text { Order } \\
\text { no. }\end{array}$ & Brief description & & \\
\hline 2 & Farmers & 9 & $12 \cdot 40$ & $\begin{array}{l}<0.001 \\
<0.01\end{array}$ & 2 & Farmers & 5 & 6.90 \\
\hline 10 & Instrument workers & 1 & 53.03 & $<0.05$ & 22 & Personal service & 30 & $1 \cdot 52$ \\
\hline 12 & Textile workers & 52 & $1 \cdot 29$ & $<0.1$ & & & & \\
\hline & & & & $<0.2$ & 7 & Textile workers & 23 & $1 \cdot 37$ \\
\hline 19 & Painters & 1 & $4 \cdot 21$ & $<0.3$ & 11 & Wood workers & 1 & 3.59 \\
\hline 20 & Workers in other materials & 1 & $1 \cdot 58$ & $<0.5$ & $\begin{array}{l}10 \\
17 \\
27\end{array}$ & $\begin{array}{l}\text { Food, drink and tobacco } \\
\text { workers } \\
\text { Transport, communication } \\
\text { Other/undefined workers }\end{array}$ & $\begin{array}{l}3 \\
1 \\
2\end{array}$ & $\begin{array}{l}1 \cdot 46 \\
1 \cdot 38 \\
2 \cdot 15\end{array}$ \\
\hline 13 & Textile goods & 15 & $1 \cdot 14$ & $<0.7$ & 19 & Professional & 8 & $1 \cdot 12$ \\
\hline 25 & Professional & 7 & $1 \cdot 05$ & $\begin{array}{l}<0.9 \\
>0.9\end{array}$ & & & & \\
\hline
\end{tabular}


between the incidence rates for the sexes for ages 15 years and above $(P<0.001)$. However, when the incidence rates were compared for each five-year age group separately, only the groups of 55 years and above showed a significant difference $(P<0.001)$.

The data on a patient's age, sex and site were available from the Registry record cards and so were complete. The remaining results were calculated from the questionnaire data. A full occupational history was available from $598(77 \%)$ of the patients with a further $148(19 \%)$ giving one main occupation only. Of the remaining $35(4 \%)$ patients there was no trace and no further information so that the following results are from the 598 and 148 patients only, $96 \%$ of the total number of registered patients with skin cancer. For these two groups of patients, where further information was available from the questionnaire, there was no significant difference between the proportions of males and females in each group $\left(\chi^{2}=0.64 ; \mathrm{df}=1 ; 0.4<\mathrm{P}<0.5\right)$ or between the proportions of each group in the different sites $\left(\chi^{2}=5.22 ; \mathrm{df}=8 ; 0.7<\mathrm{P}<0.8\right)$ so that for the results on the occupation of the patients no distinction was made between those who gave a full occupational history and those who gave one main occupation only.

The expected numbers of workers in the occupational orders are calculated in the census years 1931 and 1951 using the number of patients with skin cancer in the Manchester RHB Area in the years 1967-69. This involves the problem of whether the patient lived in the area in 1931 and 1951. Examination of the data showed that $557(71 \cdot 3 \%)$ patients lived inside the Manchester RHB Area for the census years, while only $86(11 \%)$ patients lived outside the area for one or both census years. The remaining $138(17.7 \%)$ patients did not give any residential information. However, as the number who lived outside the area was only 86 out of 643 $(557+86)$, i.e. $13 \cdot 4 \%$, no adjustments were made.

Tables $3 a$ and $b$ show, for each sex, the occupational orders with the observed numbers and the ratio of observed to expected, where the number observed was greater than the number expected, in the two census years 1931 and 1951 for all skin sites combined. The expected figures were calculated from the census data by multiplying the proportion of subjects in each occupational order at the census by

Table 4 Cancer of arms. The occupational orders with an excess of observed over expected numbers of workers for the census years 1931 and 1951 for males

\begin{tabular}{|c|c|c|c|c|c|c|c|c|}
\hline \multirow{2}{*}{\multicolumn{2}{|c|}{1931}} & \multirow{3}{*}{$\begin{array}{l}\text { Observed } \\
\text { no. }\end{array}$} & \multirow{3}{*}{$\begin{array}{l}\text { Observed/ } \\
\text { Expected }\end{array}$} & \multirow{3}{*}{$\begin{array}{l}\text { Significance } \\
\text { level }\end{array}$} & \multicolumn{2}{|l|}{1951} & \multirow{3}{*}{$\begin{array}{l}\text { Observed } \\
\text { no. }\end{array}$} & \multirow{3}{*}{$\begin{array}{l}\text { Observed } \\
\text { Expected }\end{array}$} \\
\hline & & & & & \multicolumn{2}{|c|}{ Occupation } & & \\
\hline $\begin{array}{l}\text { Order } \\
\text { no. }\end{array}$ & Brief description & & & & $\begin{array}{l}\text { Order } \\
\text { no. }\end{array}$ & Brief description & & \\
\hline & & & & $<0.001$ & & & & \\
\hline 12 & Textile workers & 18 & 1.99 & $<0.01$ & & & & \\
\hline $\begin{array}{r}1 \\
2 \\
18\end{array}$ & $\begin{array}{l}\text { Fishermen } \\
\text { Farmers } \\
\text { Builders }\end{array}$ & $\begin{array}{r}2 \\
10 \\
10\end{array}$ & $\begin{array}{r}12 \cdot 38 \\
2 \cdot 12 \\
1 \cdot 93\end{array}$ & $<0.05$ & $\begin{array}{l}5 \\
2\end{array}$ & $\begin{array}{l}\text { Chemical workers } \\
\text { Farmers }\end{array}$ & $\begin{array}{l}5 \\
8\end{array}$ & $\begin{array}{l}3 \cdot 38 \\
2 \cdot 08\end{array}$ \\
\hline $\begin{array}{l}16 \\
21\end{array}$ & $\begin{array}{l}\text { Paper workers } \\
\text { Workers in mixed/ } \\
\text { undefined materials }\end{array}$ & $\begin{array}{l}2 \\
2\end{array}$ & $\begin{array}{l}4 \cdot 71 \\
4 \cdot 01\end{array}$ & $<0.1$ & $\begin{array}{l}12 \\
25 \\
27\end{array}$ & $\begin{array}{l}\text { Paper/printing workers } \\
\text { Stationary engine drivers } \\
\text { Other/undefined workers }\end{array}$ & $\begin{array}{l}4 \\
5 \\
3\end{array}$ & $\begin{array}{l}2 \cdot 88 \\
2 \cdot 37 \\
3 \cdot 18\end{array}$ \\
\hline 6 & Chemical workers & 2 & $3 \cdot 84$ & & 6 & Metal workers & 27 & $1 \cdot 39$ \\
\hline 14 & $\begin{array}{l}\text { Food, drink and tobacco } \\
\text { workers }\end{array}$ & 3 & $2 \cdot 16$ & $<0.2$ & $\begin{array}{l}1 \\
7\end{array}$ & $\begin{array}{l}\text { Fishermen } \\
\text { Textile workers }\end{array}$ & $\begin{array}{l}1 \\
8\end{array}$ & $\begin{array}{l}9 \cdot 11 \\
1 \cdot 61\end{array}$ \\
\hline $\begin{array}{l}7 \\
9\end{array}$ & $\begin{array}{l}\text { Metal workers } \\
\text { Electrical workers }\end{array}$ & $\begin{array}{r}17 \\
3\end{array}$ & $\begin{array}{l}1 \cdot 35 \\
1 \cdot 74\end{array}$ & $<0.3$ & 3 & Miners & 4 & 1.45 \\
\hline $\begin{array}{l}11 \\
17 \\
20 \\
30\end{array}$ & $\begin{array}{l}\text { Leather workers } \\
\text { Printers } \\
\text { Workers in other materials } \\
\text { Stationary engine drivers }\end{array}$ & $\begin{array}{l}1 \\
2 \\
1 \\
2\end{array}$ & $\begin{array}{l}2 \cdot 49 \\
1 \cdot 65 \\
2 \cdot 19 \\
1 \cdot 29\end{array}$ & $<0.5$ & $\begin{array}{l}17 \\
24\end{array}$ & $\begin{array}{l}\text { Transport, communication } \\
\text { Warehouse workers }\end{array}$ & $\begin{array}{r}16 \\
4\end{array}$ & $\begin{array}{l}1 \cdot 22 \\
1 \cdot 16\end{array}$ \\
\hline \multirow[t]{2}{*}{$\begin{array}{l}25 \\
22\end{array}$} & $\begin{array}{l}\text { Professional } \\
\text { Transport, communication }\end{array}$ & $\begin{array}{r}3 \\
17\end{array}$ & $\begin{array}{l}1 \cdot 09 \\
1 \cdot 11\end{array}$ & $<0.7$ & 8 & Leather workers & 1 & $1 \cdot 07$ \\
\hline & & & & $\begin{array}{l}<0.9 \\
>0.9\end{array}$ & 14 & Builders & 7 & $1 \cdot 11$ \\
\hline
\end{tabular}


Table 5 Cancer of ears. The occupational orders with an excess of observed over expected numbers of workers for the census years 1931 and 1951 for males

\begin{tabular}{|c|c|c|c|c|c|c|c|c|}
\hline \multirow{2}{*}{\multicolumn{2}{|c|}{$\frac{\text { I93I }}{\text { Occupation }}$}} & \multirow{3}{*}{$\begin{array}{l}\text { Observed } \\
\text { no. }\end{array}$} & \multirow{3}{*}{$\begin{array}{l}\text { Observed/ } \\
\text { Expected }\end{array}$} & \multirow{3}{*}{$\begin{array}{l}\text { Significance } \\
\text { level }\end{array}$} & \multicolumn{2}{|l|}{1951} & \multirow{3}{*}{$\begin{array}{l}\text { Observed } \\
\text { no. }\end{array}$} & \multirow{3}{*}{$\begin{array}{l}\text { Observed } \\
\text { Expected }\end{array}$} \\
\hline & & & & & \multicolumn{2}{|c|}{ Occupation } & & \\
\hline $\begin{array}{l}\text { Order } \\
\text { no. }\end{array}$ & Brief description & & & & $\begin{array}{l}\text { Order } \\
\text { no. }\end{array}$ & Brief description & & \\
\hline 2 & Farmers & 14 & $2 \cdot 72$ & $<0.001$ & & & & \\
\hline \multirow[t]{3}{*}{12} & Textile workers & 18 & $1 \cdot 82$ & $<0.01$ & $\begin{array}{l}2 \\
7\end{array}$ & $\begin{array}{l}\text { Farmers } \\
\text { Textile workers }\end{array}$ & $\begin{array}{l}12 \\
11\end{array}$ & $\begin{array}{l}2 \cdot 97 \\
2 \cdot 11\end{array}$ \\
\hline & & & & $<0.05$ & $\begin{array}{r}3 \\
14\end{array}$ & $\begin{array}{l}\text { Miners } \\
\text { Builders }\end{array}$ & $\begin{array}{r}7 \\
12\end{array}$ & $\begin{array}{l}2 \cdot 42 \\
1 \cdot 81\end{array}$ \\
\hline & & & & $<0.1$ & & & & \\
\hline 24 & $\begin{array}{l}\text { Public administration and } \\
\text { defence }\end{array}$ & 3 & $2 \cdot 59$ & $<0.2$ & 22 & Personal service & 6 & $1 \cdot 64$ \\
\hline 9 & Electrical workers & 4 & $2 \cdot 12$ & & & & & \\
\hline 18 & Builders & 9 & $1 \cdot 59$ & & & & & \\
\hline 19 & Painters & 4 & $1 \cdot 87$ & & & & & \\
\hline 14 & $\begin{array}{l}\text { Food, drink and tobacco } \\
\text { workers }\end{array}$ & 3 & 1.97 & & & & & \\
\hline 7 & Metal workers & 17 & $1 \cdot 24$ & $<0.3$ & $\begin{array}{r}15 \\
8\end{array}$ & $\begin{array}{l}\text { Painters } \\
\text { Leather workers }\end{array}$ & $\begin{array}{l}4 \\
2\end{array}$ & $\begin{array}{l}1 \cdot 64 \\
2 \cdot 04\end{array}$ \\
\hline 5 & $\begin{array}{l}\text { Brick, pottery and glass } \\
\text { workers }\end{array}$ & 1 & $1 \cdot 86$ & $<0.5$ & $\begin{array}{r}21 \\
4\end{array}$ & $\begin{array}{l}\text { Entertainment, sport } \\
\text { Non-metalliferous product }\end{array}$ & $\begin{array}{l}1 \\
1\end{array}$ & $\begin{array}{l}1 \cdot 56 \\
1 \cdot 53\end{array}$ \\
\hline 21 & $\begin{array}{l}\text { Workers in mixed/undefined } \\
\text { materials }\end{array}$ & 1 & $1 \cdot 83$ & & & workers & & \\
\hline 30 & Stationary engine drivers & 2 & $1 \cdot 18$ & $<0.7$ & & & & \\
\hline $\begin{array}{r}3 \\
26\end{array}$ & Miners & 7 & $1 \cdot 27$ & & & & & \\
\hline \multirow{2}{*}{26} & 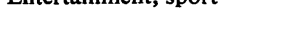 & 1 & 110 & & & & & \\
\hline & & & & $>0.9$ & 0 & 1 & 22 & 100 \\
\hline
\end{tabular}

Table 6(a) The distribution of male patients by eye colour and site of cancer

\begin{tabular}{lrrrrr}
\hline Eye colour & \multicolumn{3}{l}{ Site of cancer } & \multirow{2}{*}{ Total } \\
\cline { 2 - 5 } & Head & Body & Arms & Legs & \\
\hline Grey/blue & 109 & 17 & 54 & 13 & 193 \\
Green* & 2 & 0 & 3 & 0 & 5 \\
Hazel & 43 & 7 & 26 & 2 & 78 \\
Brown/dark & 38 & 2 & 12 & 5 & 57 \\
Total & 192 & 26 & 95 & 20 & 333 \\
\hline
\end{tabular}

$\chi^{2}=6.79 ; \mathrm{df}=6 ; 0.3<\mathrm{P}<0.5$

*Colour not used in the statistical tests.

Table 6(b) The distribution of female patients by eye colour and site of cancer

\begin{tabular}{lccccc}
\hline Eye colour & \multicolumn{3}{l}{ Site of cancer } & \multicolumn{2}{c}{ Total } \\
\cline { 2 - 5 } & Head & Body & Arms & Legs & \\
\hline Grey/blue & 63 & 18 & 15 & 26 & 122 \\
Green* & 3 & 1 & 1 & 2 & 7 \\
Hazel & 31 & 2 & 6 & 13 & 52 \\
Brown/dark & 22 & 6 & 2 & 10 & 40 \\
Total & 119 & 27 & 24 & 51 & 221 \\
\hline
\end{tabular}

$x^{2}=6.18 ; \mathrm{df}=6 ; 0.3<\mathrm{P}<0.5$

*Colour not used in the statistical tests.
Table 7(a) The distribution of male patients by atopy and site of cancer

\begin{tabular}{lccccc}
\hline Atopic & \multicolumn{3}{l}{ Site of cancer } & \multirow{2}{*}{ Total } \\
\cline { 2 - 5 } & Head & Body & Arms & Legs & \\
\hline Yes & 32 & 10 & 13 & 1 & 56 \\
No & 96 & 17 & 76 & 12 & 201 \\
Total & 128 & 27 & 89 & 13 & 257 \\
\hline
\end{tabular}

$x^{2}=8.67 ;$ df $=3 ; 0.01<P<0.05$

Table 7(b) The distribution of female patients by atopy and site of cancer

\begin{tabular}{llcccc}
\hline Atopic & \multicolumn{3}{l}{ Site of cancer } & \multirow{2}{*}{ Total } \\
\cline { 2 - 5 } & Head & Body & Arms & Legs & \\
\hline Yes & 17 & 7 & 8 & 7 & 39 \\
No & 59 & 13 & 11 & 22 & 105 \\
Total & 76 & 20 & 19 & 29 & 144 \\
\hline
\end{tabular}

$x^{2}=3.79 ;$ df $=3 ; 0.2<P<0.3$ 
the total number of patients at work in the study. The occupational order of 'retired/not gainfully employed' was not used in this and subsequent analyses as it would tend to be under-represented in 1931 and over-represented in 1951, these findings merely being reflections of the age distribution of the population. The occupational orders in the Tables are ranked according to the significance levels of the excess of observed over expected numbers. The significance levels were calculated using the $\chi^{2}$ test when the expected number was five or greater, and the Poisson distribution when the expected number was less than five.

A similar analysis was then performed for the skin cancer sites where there were sufficient numbers. Only sites with 100 or more patients were chosen as this number ensures that, when the patients not at work are excluded, there are still sufficient for the statistical tests to be valid. Tables 4 and 5 show for males the occupational orders, observed numbers and the ratio of observed to expected numbers in the two census years for the arms and ears respectively.

In the remaining Tables the sites have been grouped together to form four skin sites, so that the numbers of patients in individual cells are large enough for statistical validity. The four regions are the legs, the arms, the body (consisting of the trunk and for the males the scrotum) and the head (consisting of the lips, eyelids, ears, face, scalp and neck).

Tables $6 a$ and $b$ show the distribution of patients by eye colour and site for each sex. A $\chi^{2}$ test was performed for each sex to determine whether there was a significant association between eye colour and site. No significant association was found for males $\left(\chi^{2}=6.79 ; \mathrm{df}=6 ; 0.3<\mathrm{P}<0.5\right)$ or for females $\left(\chi^{2}=6 \cdot 18 ; \mathrm{df}=6 ; 0.3<\mathrm{P}<0.5\right)$.

Table 8 The distribution of male patients by tropical residence and site of cancer

\begin{tabular}{lccccc}
\hline Residence & \multicolumn{3}{l}{ Site of cancer } & & \multirow{2}{*}{ Total } \\
\cline { 2 - 5 } & Head & Body & Arms & Legs & \\
\hline Tropical & 36 & 4 & 14 & 7 & 61 \\
Non-tropical & 177 & 35 & 89 & 12 & 313 \\
Total & 213 & 39 & 103 & 19 & 374 \\
\hline
\end{tabular}

$\chi^{2}=7.53 ; \mathrm{df}=3 ; 0.05<\mathrm{P}<0.1$

Tables $7 \mathrm{a}$ and $\mathrm{b}$ show the distribution of patients by atopy and site for each sex. A subject was defined as atopic by the presence (or history) of asthma, hay fever or skin sensitisation. For the males there was a significant difference in the proportion of atopic patients in each site $\left(\chi^{2}=8.67 ; \mathrm{df}=3 ; 0.01<\mathrm{P}\right.$ $<0.05)$ : however, this was not found for females $\left(\chi^{2}=3.79 ; \mathrm{df}=3 ; 0.2<\mathrm{P}<0.3\right)$.

Residence for a year or more in tropical or hot climates was noted for each patient. Table 8 shows the distribution of patients by residence in the tropics and site for males alone, as there were only

Table 9(a) The distribution of male patients by smoking habit and site of cancer. The figures in parentheses show the number of patients with cancer of the lip

\begin{tabular}{|c|c|c|c|c|c|c|}
\hline \multirow[t]{2}{*}{ Smoking habit } & \multicolumn{5}{|c|}{ Site of cancer } & \multirow[t]{2}{*}{ Total } \\
\hline & Head & $($ Lip $)$ & Body & Arms & Legs* & \\
\hline $\begin{array}{l}\text { Pipe smokers } \\
\text { Non-smokers } \\
\text { Cigarette smokers }\end{array}$ & $\begin{array}{r}33 \\
17 \\
166\end{array}$ & $\begin{array}{l}(2) \\
(1) \\
(10)\end{array}$ & $\begin{array}{r}4 \\
6 \\
24\end{array}$ & $\begin{array}{r}15 \\
9 \\
67\end{array}$ & $\begin{array}{r}3 \\
3 \\
15\end{array}$ & $\begin{array}{r}55 \\
35 \\
272\end{array}$ \\
\hline Total & 216 & (13) & 34 & 91 & 21 & 362 \\
\hline
\end{tabular}

Between pipe and non-smokers: $x^{2}=2.39 ; \mathrm{df}=2 ; 0.3<\mathrm{P}<0.5$

Between cigarette and non-smokers: $x^{2}=3.51$; df $=3 ; 0.3<P<0.5$

* Site not used in the comparison between pipe and non-smokers.

Table 9(b) The distribution of female patients by smoking habit and site of cancer. The figures in parentheses show the number of patients with cancer of the lip

\begin{tabular}{lclccccc}
\hline & \multicolumn{2}{c}{ Site of cancer } & & & \multicolumn{2}{c}{ Total } \\
\cline { 2 - 6 } & Head & (Lip) & Body & Arms & Legs & \\
\hline Pipe smokers & 0 & $(0)$ & 0 & 1 & 0 & 1 \\
Non-smokers & 103 & $(1)$ & 25 & 18 & 43 & 189 \\
Cigarette smokers & 31 & $(1)$ & 6 & 5 & 16 & 58 \\
Total & 134 & $(2)$ & 31 & 24 & 59 & 248 \\
\hline
\end{tabular}

Between pipe and non-smokers: not tested.

Between cigarette and non-smokers: $x^{2}=0.78 ; \mathrm{df}=3 ; 0.8<\mathrm{P}<0.9$ 
four females in this group. (The 61 male patients had a median duration in the tropics of 4.7 years and a range of 1-44 yr; however, only five had spent 15 years or more in the tropics.) No significant association between tropical residence and skin cancer site was found $\left(\chi^{2}=7.53 ; \mathrm{df}=3 ; 0.05<\mathrm{P}<0.1\right)$.

Tables $9 \mathrm{a}$ and $\mathrm{b}$ show the distribution of patients by smoking habit and site for each sex. A cigarette smoker was a patient who had smoked one or more cigarettes per day for at least a year, and a pipe smoker was one who had smoked at least a quarter-ounce of tobacco per week for at least a year. For the males there was no significant difference between the ratio of pipe smokers to non-smokers in each site $\left(\chi^{2}=2.39\right.$; df $\left.=2 ; 0.3<\mathrm{P}<0.5\right)$. For both sexes a test was performed on the ratio of cigarette to non-smokers in each site; no significant differences were found for the males $\left(\chi^{2}=3.51\right.$; $\mathrm{df}=3 ; 0.3<\mathrm{P}<0.5)$ or the females $\left(\chi^{2}=0.78\right.$; $\mathrm{df}=3 ; 0.8<\mathrm{P}<0.9$ ).

\section{Discussion}

Table 1 shows that there are significant differences in the proportions of males and females between the sites, and Table 2 shows that there are significant differences in the incidence rates for males and females in the higher age groups, which comprise about $89 \%$ of the patients. This suggests that the factors causing skin cancer are either different for each sex or that there are different degrees of exposure for each sex.

Emmett (1975) has stated that 'Such information as is available makes it abundantly clear that in lightly pigmented people solar radiation is far and away the major cause of skin cancer...' Although all the patients in this study were white, solar radiation does not satisfactorily account for all the observed differences. For example, solar radiation may account for the differences in the leg (as females wear dresses), the ear (as females tend to have longer hair) and the arm (as males tend to work outdoors) but it does not account for the differences in the face or trunk.

This issue is further complicated by the results on tropical residence (Table 8). Either solar radiation affects all sites equally, regardless of exposure, or solar radiation in the tropics with a median duration of 4.7 years did not have an appreciable effect compared with the solar radiation in Britain. In view of the current findings that exposure to solar radiation is a contributory factor to skin cancer (Carmichael and Silverstone, 1961; Emmett, 1975) the latter explanation is the more likely. The preceding arguments suggest that solar radiation is not the only factor causing skin cancer.
A number of occupational factors have been stated by Emmett (1975) to be causes of skin cancer. These include ultraviolet radiation, pitch, tar, shale and mineral oils with minor causes given as arsenic, burns, trauma and ionising radiation.

A number of occupational orders show consistent excesses of observed over expected numbers (Tables 3, 4 and 5). For all sites combined, the farmers show an excess of about $150 \%$ for males in both census years. This category consists of farm workers, gardeners, groundsmen and foresters. For females the excess varies from $1140 \%$ to $590 \%$ in 1931 and 1951 respectively. All these excesses are highly significant. Where the examination of individual sites was possible we again find that they show excesses of about $190 \%$ for the ears and $110 \%$ for the arm. Taken together, these results confirm the mortality study of Atkin et al. (1949) and, because the excesses occur in sites exposed to the sun, the probable cause is solar radiation.

For all sites combined, textile workers show highly significant excesses of about $135 \%$ for males in both census years. The corresponding excess for females is smaller at about $30 \%$ in both census years and does not reach significance. The reason for this difference in the size of the excess is not clear, but may be attributable to the different types of textile job performed. Approximately $70 \%$ of the females were winders or weavers (General Register Office, $1934 \mathrm{a}, 1956 \mathrm{a}$ ) whereas $50 \%$ of the males were spinners or their assistants. Scrotal cancer is known to be associated with textile workers, in particular mule spinners (Henry, 1946; Lee et al., 1972). There is evidence that, during the years 1967-69 (Lloyd Davies 1968, 1969, 1970), in the cotton industry the scrotum was not the only site affected by mineral oil. In those years there were 18 notifications of epitheliomatous ulceration of the skin where mineral oil in the cotton industry was accepted as the cause, of which 13 cancers were scrotal, four were on the arm and the remaining one was on the face or head. The number of men with scrotal cancer was 35 and too small to give valid results from an analysis of their occupations. However, in the present study both the arms and ears show excesses, the arms of $99 \%$ and $61 \%$ and the ears of $82 \%$ and $111 \%$ in 1931 and 1951 respectively.

No other occupations show notable excesses for the females. The occupational orders of instrument makers, painters and wood workers show large excesses but are based on one person only for each occupation. The occupational order of personal service workers, while showing a $52 \%$ and significant excess in 1951, shows a deficit in 1931. The reason for this is not clear. A similar finding occurs with workers in the other/undefined category, but 
this includes only two females.

For males, other occupations show excesses for all sites combined. The occupational order of metal workers shows an excess of $38 \%$ and $23 \%$ in 1931 and 1951 respectively. However these excesses are of borderline significance. When the arm alone is considered there are non-significant excesses of $35 \%$ in 1931 and $39 \%$ in 1951 . There are similar findings for the ear, where there is an excess of $24 \%$ in 1931 but only $8 \%$ excess in 1951 ; neither excess is significant. Metal workers, including machine operators and fitters, are exposed to mineral oils and grease which are believed to be important factors in the development of scrotal cancer; $33 \%$ of the metal workers in this survey were machine operators. The results provide confirmation of the findings of Cruickshank and Squire (1950) and of Spink et al. (1964). There is also a tendency for the excess to occur in the earlier period of 1931.

Building workers show excesses of $38 \%$ and $13 \%$ in 1931 and 1951 respectively, for all sites combined. When considered by site there are excesses of $93 \%$ and $11 \%$ for the arm and $59 \%$ and $81 \%$ for the ears in 1931 and 1951 respectively. Only two of these results are statistically significant, but taken together they indicate an association between the building occupation and skin cancer. There is also a tendency for the larger excesses to occur in the earlier period, 1931. These are mainly outdoor workers, with solar radiation or building materials such as tar or wood (creosote) as their recognised hazards.

Chemical workers show excesses of $59 \%$ and $49 \%$ in 1931 and 1951 respectively for all sites combined. These excesses are mainly confined to the arm where there are excesses of $284 \%$ and $238 \%$. These workers are clearly exposed to the chemicals they handle. Although these results are of borderline statistical significance because of the small numbers of workers involved, this finding, taken with that of Lee et al. (1972), that dye workers may be at risk from scrotal cancer, suggests that further investigation may be warranted. Similar results are found for fishermen. The excesses found for all sites combined are repeated only when the arm is considered. However, there were only two fishermen, one having retired in 1951, and both had cancer of the arm, so that the large excesses are of borderline statistical significance.

When the arm is considered, the occupations of paper and printing workers show as an excess. In 1931 this occupation is split into the two constituent parts and the paper workers have an excess of $371 \%$ while the printers have an excess of $65 \%$. In 1951 the occupation is not split up and there is an excess of $188 \%$. For all sites combined there are small excesses of both paper and printing workers in 1931 but this is followed by a deficit in 1951, so that while these workers do not appear to be at risk in general, there is a tendency for them to have excess of cancer of the arm. Caution must be observed in interpreting the results for the paper workers as there were only two in the study, both with cancer of the arm, and there is no clear hazard. However there are more printers, and there are the recognised hazards of the ink and ultraviolet radiation (to lithographers).

Other occupations have smaller although consistent excesses for all sites combined; these occupations include stationary engine drivers, and brick, pottery and glass workers (in 1951 the equivalent occupation is called non-metalliferous product workers). Both these excesses are repeated when considering the individual sites, for the arm in stationary engine drivers, and for the ears in brick, pottery and glass workers. However, these excesses are not statistically significant and are based on small numbers.

Two further occupations, miners, and food, drink and tobacco workers, have excesses in one of the census years only, for all sites combined and also for the arm and ears. The miners have their large excesses in 1951, but only for the ears does the excess reach the $5 \%$ significance level. The food, drink and tobacco workers have their excesses in 1931 but these are not statistically significant. The reason for these excesses is puzzling as there is no recognised hazard in either of these occupations. However, for the miners one may speculate that the differences between the two census years may be caused, in some part, by increased mechanisation, in particular the use of high-speed drills.

Gellin et al. $(1965,1969)$ in two surveys found that basal cell cancer and malignant melanoma are associated with eye colour, hair colour, complexion, ability to tan, outdoor exposure and personal and family history of skin cancer. This present survey, which does not have any control subjects, cannot confirm or deny the hypothesis that eye colour or atopy may also be factors associated with squamous cell cancer. However, the possibility that differences in eye colour or atopy may cause certain sites to be more susceptible to skin cancer was considered. The results on eye colour give no indication that this hypothesis applies to squamous cell cancer, as no significant association was found. The results for atopy, as defined, show for the males a significant difference in the proportions of atopics between the sites. However, as the result was significant only at the $5 \%$ level and the females did not show a similar result, caution must be used in interpreting the results. 
The results from the analysis of Tables $9 \mathrm{a}$ and $b$ indicate that, for both sexes, there is no association between site and whether or not a person smoked either a pipe or cigarettes. Atkin et al. (1949) have stated that, in addition to solar radiation, smoking, in particular pipe smoking, is a possible factor in cancer of the lip. However, when the lip was compared with all other sites combined, no significant associations were found with smoking. The results, using Fisher's Exact Test*, are not significant for the males between pipe and non-smokers $(0.6<P$ $<0.7)$ or between cigarette and non-smokers $(0.6<\mathrm{P}<0.7)$. In addition, the comparison between lip cancer and other sites is not significant, for females, between cigarette and non-smokers $(P>0.9)$. These results do not show any association between smoking, either pipes or cigarettes, and lip cancer. However this result should be viewed in the knowledge that there was only a small number of patients with lip cancer (18 male and three female), and that Keller (1970) indicates that it is cancer of the mucous membrane, a site not included in this survey, which is related to smoking.

\section{Conclusions}

From the previous results and discussion there is strong evidence of an association between farming and skin cancer. For textile workers there is also strong evidence of an excess, but when considering the differences between males and females, the association is mainly with spinning. For the metal workers there is evidence of an association with skin cancer, with a tendency for the excesses to occur in the earlier period, 1931. Building workers show similar results to the metal workers, but with the excesses being larger for the ears. Chemical workers, fishermen and paper/printing workers show an association which is restricted to cancer of the arm. Stationary engine drivers and brick, pottery and glass workers show a slight association with cancer of the arms and ears respectively.

We are grateful to the Manchester Regional Hospital Board for financial support for this investigation, to Dr I. Leck of the Manchester Regional Cancer Registry, to Dr M. Garretts, for advice in the early stages of the investigation and to the Consultants and general practitioners looking after the patients for their help and co-operation.

* A one-tailed test of a $2 \times 2$ contingency table for small numbers.
References

Alderson M. R. (1976). An Introduction to Epidemiology, pp. 21-23. Macmillan Press: London.

Atkin, M., Fenning, J., Heady, J. A., Kennaway, E. L., and Kennaway, N. M. (1949). The mortality from cancer of the skin and lip in certain occupations. British Journal of Cancer, 3, 1-15.

Carmichael, G. G., and Silverstone, H. (1961). The epidemiology of skin cancer in Queensland: the incidence. British Journal of Cancer, 15, 409-424.

Cruickshank, C. N. D., and Squire, J. R. (1950). Skin cancer in the engineering industry from the use of mineral oil. British Journal of Industrial Medicine, 7, 1-11.

Emmett, E. A. (1975). Occupational skin cancer: a review. Journal of Occupational Medicine, 17, 44-49.

Gellin, G. A., Kopf, A. W., and Garfinkel, L. (1965). Basal cell epithelioma: a controlled study of associated factors. Archives of Dermatology, 91, 38-45.

Gellin, G. A., Kopf, A. W., and Garfinkel, L. (1969). Malignant melanoma: a controlled study of possibly associated factors. Archives of Dermatology, 99, 43-48.

General Register Office (1934a). Census of England and Wales, 1931-Classification of Occupations, HMSO: London.

General Register Office (1934b). Census of England and Wales, 1931-Occupational Mortality Tables. HMSO: London.

General Register Office (1956a). Census of England and Wales, 1951-Classification of Occupations. HMSO: London.

General Register Office (1956b). Census of England and Wales, 1951-Occupational Mortality Tables. HMSO: London.

General Register Office (1968). Statistical Review of England and Wales, 1967. HMSO: London.

General Register Office (1970). Statistical Review of England and Wales, 1968. HMSO: London.

General Register Office (1971). Statistical Review of England and Wales, 1969. HMSO: London.

Henry, S. A. (1946). Cancer of the Scrotum in Relation to Occupation, pp. 38-63. Oxford University Press: London.

Keller, A. Z. (1970). Cellular types, survival, race, nativity, occupations, habits and associated diseases in the pathogenesis of lip cancers. American Journal of Epidemiology, 91, 486-499.

Lee, W. R., Alderson, M. R., and Downes, Jean E. (1972). Scrotal cancer in the North-west of England, 1962-68. British Journal of Industrial Medicine, 29, 188-195.

Lloyd Davies, T. A. (1968). Annual Report of HM Chief Inspector of Factories for 1967, pp. 91-93. HMSO : London.

Lloyd Davies, T. A. (1969). Annual Report of HM Chief Inspector of Factories for 1968, pp. 58-62. HMSO: London.

Lloyd Davies, T. A. (1970). Annual Report of HM Chief Inspector of Factories for 1969, pp. 67-72. HMSO: London,

Spink, M. S., Baynes, A. H., and Tombleson, J. B. L. (1964). Skin carcinoma in the process of 'Stanford Jointing'. British Journal of Industrial Medicine, 21, 154-157.

Wahlberg, J. E., and Johansson, G. (1977). Skin cancer of the hand and arm in Sweden 1966-70 in relation to previous occupational exposure. Berufsdermatosen, 25, 185-195.

World Health Organization (1967). International Classification of Diseases, Eighth revision. WHO: Geneva. 